\title{
サーマルマネージメント研究の動向
}

\section{Research Trend of Thermal Management}

サーマルマネージメント研究会

\section{1.はじめに}

近年, 車載向け, ロボット向けなどパワーエレクトロニ クス分野の活況にも見えるように, 機器の電動化が進展し ており, サーマルマネージメントの重要性が増している。 本稿では, 2018 年に開催された以下の国内で開催された国 際学術会議 1 件および学術講演会 2 件, アメリカで開催さ れた国際学術会議 2 件における口頭発表の動向を通して, サーマルマネージメントマネージメント研究のトレンドを 紹介する。

•ICEP-IAAC2018（国内開催の国際学術会議）

・第 55 回日本伝熱シンポジウム（国内の学術講演会）

・熱工学コンファレンス 2018（国内の学術講演会）

・ITherm2018（アメリカ開催の国際学術会議）

・InterPACK2018（アメリカ開催の国際学術会議）

\section{2. 国内で開催された学術講演会および国際会議にお ける研究動向}

本章では, 国内で開催された学術講演会および国際会 議における研究動向を示す。調査対象としたのは, ICEP (International Conference on Electronics Packaging), 日本伝熱 シンポジウム, 熱工学コンファレンスである。ICEP はエレ クトロニクス実装学会が主催する学術国際会議で, 毎年 4 月に日本国内で開催される。日本在住者の他, アジアから の参加者が多いのが特徵である。ここでは, サーマルマ ネージメントに関連するセッションの状況について示す。 一方, 日本伝熱シンポジウムは日本伝熱学会が主催, 熱工 学コンファレンスは日本機械学会熱工学部門が主催する,

熱流体現象全般を扱う国内の学術講演会で, それぞれ毎年 5 月末頃および 10 月末頃に開催され, 熱工学にかかわる国 内の研究者, 技術者が数多く参加する。これら 2 つ学術 講演会は全体が熱に関するものであるため, ここでは, エ レクトロニクス実装学会の分野にあたる電子機器のセッ ションの状況について主に示す。

\subsection{ICEP-IAAC2018 の概要}

今年度の ICEP は iMAPS が主催する IAAC (iMAPS All Asia
Conference) との合同開催で, ICEP-IAAC 2018 として 2018 年 4 月 17 日から 4 月 20 日まで三重県桑名市のホテル花水 木で開催された。サーマルマネージメント研究について は, “Thermal Management” 2 セッションの他, “Materials and Processes: thermal solution” 1 セッションが設けられ，合わせ て 3 セッション計 12 件の発表があった ${ }^{1)} 。 2.4$ 節に示す分 類はこれら計 3 セッションに関するものである。

\section{2 第 55 回日本伝熱シンポジウムの概要}

第 55 回日本伝熱シンポジウムは, 2018 年 5 月 29 日から 5 月 31 日まで札幌コンベンションセンターで開催され, 計 74 セッションが設けられた。電子機器関連では, 昨年度に 続き「電子機器の冷却」セッションが設定され, 3 セッショ ン計 12 件の発表があった ${ }^{2)}$ 。2.4 節に示す分類は「電子機 器の冷却」セッションに関するものである。なお, 今年度 は電子機器の冷却に近い分野である「ヒートパイプ」セッ ションが別途設定され, 2 セッション計 7 件の発表があっ た。そのため,「電子機器の冷却」セッションにおけるヒー トパイプに関する発表は 1 件に留まっている。

\section{3 熱工学コンファレンス 2018 の概要}

熱工学コンファレンス 2018 は, 2018 年 10 月 20 日から 10 月 21 日まで富山大学で開催され, 計 46 セッションが設 けられた。電子機器関連では 2016 年に続き「電子機器・デ バイスのサーマルマネジメント」セッションがオーガナイ ズドセッションとして企画され， 5 セッション計 20 件の発 表があった ${ }^{3)}$ 。 2.4 節に示す分類は「電子機器・デバイスの サーマルマネジメント」セッションに関するものである。 また, 10 月 20 日昼には「産業界で求められる伝熱研究」と 題して熱工学ワークショップが企画され, (1)ヒートパイ プ, (2) LED を題材にしたVHDL-AMS によるマルチドメイ ンモデリング, (3)バイナリ発電と熱エネルギマネジメント の 3 題について講演者から話題提供, その後短時間では あったがパネル形式で議論が行われた。

\section{4 サーマルマネージメント研究に関する発表の分類}

昨年の記事 ${ }^{4)}$ を参考に, 講演発表を以下の 8 分野に分類 する。(1)高発熱機器の冷却（沸騰冷却を含む), (2)パワーエ レクトロニクス（バッテリーや $\mathrm{SiC}$ などを対象にした複合 


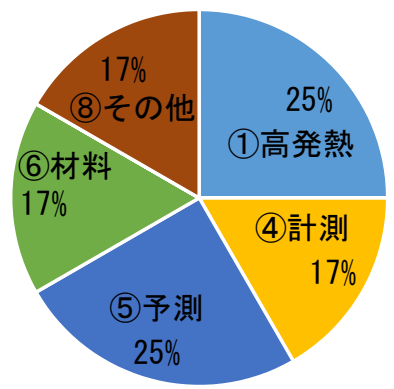

図 1. ICEP-IAAC2018 におけるサーマルマネージメント研 究発表

的な内容), (3)ヒートパイプ, (4)計測技術, (5)温度予測・シ ミュレーション技術, (6)材料開発, (7)単相流冷却, (8)その 他, である。なお, 昨年の分類では上記の他に, 「データセ ンター（スーパーコンピュータ関係を含む）」があったが, (1)との分類が難しいケースが多く, また, 後述するアメリ カでの状況とは異なり, 今年度はデータセンターに直結す る研究発表が行われていないことから除外した。

図 1 にICEP-IAAC2018 におけるサーマルマネージメント に関連する計 12 件の発表の分類を示す。昨年に続き(1)高発 熱機器の冷却は割合が大きく, 沸騰冷却を中心に $1 / 4(3$ 件）を占めた。また，シミュレーションを核とした発表の 割合も多く，5温度予測・シミュレーション技術も 1/4（3 件）を占めた。エレクトロニクス実装学会の国際会議らし く，材料や実装に関する発表も 3 件あり，66材料開発，8 その他に分類されている。

図 2 に第 55 回日本伝熱シンポジウムの「電子機器の冷 却」セッションにおける計 12 件の発表の分類を示す。(1)高 発熱機器の冷却, (2)パワーエレクトロニクスで過半（計 7 件）を占めており，これは昨年度の傾向と同様である。な お, 上述の通り, 今年度は「ヒートパイプ」セッションが 設定されたため, 眓 2 におけるヒートパイプに関する発表 は 8\%（1 件）と少なくなっている。なお, ヒートパイプに ついては, 近年はループヒートパイプ, 自励振動ヒートパ イプに関する研究が活発なようである。

図 3 に熱工学コンファレンス 2018 の「電子機器・デバイ スのサーマルマネジメント」セッションにおける計 20 件の 発表の分類を示す。比較的多くの分類に属する発表があっ たが，(4)計測技術，(5)温度予測・シミュレーション技術の 2 つで発表の半数 (計 10 件) を占めている点が興味深い。 (4)計測技術については，接触熱抵抗や熱電対の測定精度な どに関する発表であった。また, 5温度予測・シミュレー ション技術についても, うち 2 件は熱流センサを用いた発 熱量や熱抵抗值の推定, 1 件は接触熱抵抗の評価をシミュ レーションを用いて行ったもので, 今後ますます小型・軽 量化が求められるエレクトロニクス分野で精度の高い計測 やシミュレーション技術が求められている現状と重なる。

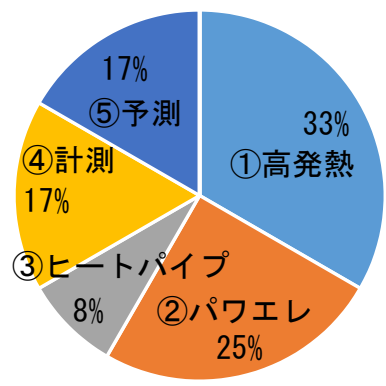

特

図 2. 第 55 回日本伝熱シンポジウムにおける電子機器関 連の研究発表

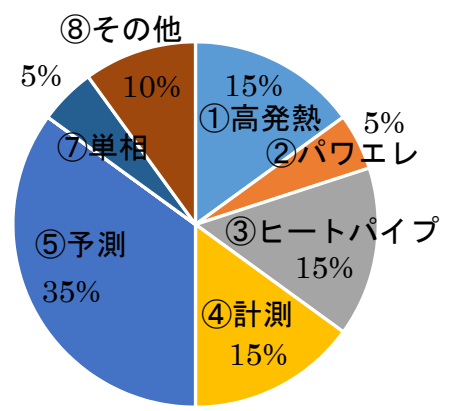

図 3. 熱工学コンファレンス 2018 における電子機器関連 の研究発表

\section{3. アメリカで開催された学術国際会議における研究 動向}

本章では, アメリカで開催された国際会議での研究動向 をまとめる。対象としたのは, ITherm と InterPACK であ る。ITherm は IEEE EPS (Electronics Packaging Society) が主 催する学術国際会議で, 2014 年までは隔年開催であった が，2016 年からは毎年開催されている。一方, InterPACK はアメリカ機械学会 (ASME) が主催する学術国際会議で, 2015 年までは隔年開催，2017 年からは毎年開催されてい る。

\subsection{ITherm 2018}

1988 年の初回開催からちょうど 30 周年にあたる ITherm 2018 は 5 月 29 日から 6 月 1 日の 4 日間, カリフォルニア 州サンディエゴで開催された。口頭発表については，4つ のトラック, 計 50 のセッションで構成された ${ }^{5)}$ 。なお, 今 年度は, 上述の日本伝熱シンポジウム 2018 と日程が被って しまっており，筆者を含め，日本の特に熱工学に近い研究 者および技術者の参加が難しい。来年度も残念ながらこの 状況は続くようである。

表 1 に ITherm2018 における口頭発表のトラックとセッ ションを一覧で示す。表 1 に示す通り, IThermのセッショ ンはアルファベットと番号の組み合わせで表示される。ア ルファベットはトラックを, 番号は個別のセッションを意 味するが，番号が同じセッションは同時開催される。似た セッションで番号が離れているケースがあるのはそのため 
である。昨年度の ITherm2017 と同様に，11エマージング技 術と基礎，(2)コンポーネントレベルおよび(3)システムレベ ルのサーマルマネージメント, (4)構造と信頼性に関する 4 つのトラックが設けられた。後述するInterPACKにも言え ることであるが，日本国内における学術講演会との大きな

表 1. ITherm 2018 におけるトラックとセッション構成

\begin{tabular}{l|l}
\hline EMERGING TECHNOLOGIES \& FUNDAMENTALS \\
\hline E-1 & Fundamentals of Boiling and Condensation \\
E-2 & Flexible Electronics \\
E-3 & Thermal Transport in Nanotechnology \\
E-4 & Thermal Numerical Methods, Nano-To-Macro Scale \\
E-5 & Thermal Interface Materials and Phase Change Materials I \\
E-6 & Thermal Interface Materials and Phase Change Materials II \\
E-7 & Convection in Channels and Jets \\
E-9 & Thermal Experimental Methods, Nano-To-Macro Scale I \\
E-10 & Thermal Experimental Methods, Nano-To-Macro Scale II \\
E-11 & Emerging Materials and Thermal Phenomena I \\
E-12 & Emerging Materials and Thermal Phenomena II \\
\hline
\end{tabular}

COMPONENT-LEVEL THERMAL MANAGEMENT

\section{TI-1A $\quad$ 3D Packaging / 3D Embedded Cooling I}

TI-1B Vapor Chambers and Heat Pipes

TI-2 3D Packaging / 3D Embedded Cooling II

TI-3 Single/Multi Chip Module (MCM) and System in Package (SIP) I

TI-4 Single/Multi Chip Module (MCM) and System in Package (SIP) I

TI-5 Hot Spot Cooling and Jet Impingement I

TI-6 Hot Spot Cooling and Jet Impingement II

TI-7A Thermal Interface Materials, Heat Spreaders, and Thermal Ground Planes

TI-7B Air Cooling and Heat Exchangers

TI-8A Novel Air Cooling Devices and Systems

TI-8B Characterization of Materials and Structures for Thermal Management of Electronics

TI-9 Board-Level Liquid Cooling Solutions

TI-10 Boiling, Condensation, Evaporation, and Microgap Cooling I

TI-11 Boiling, Condensation, Evaporation, and Microgap Cooling II

TI-12A Single/Two-Phase Flow in Microchannels and Cold Plates

TI-12B Thermoelectricity, TEC, and Peltier Devices

SYSTEM-LEVEL THERMAL MANAGEMENT

\begin{tabular}{l|l}
\hline TII-1 & Data Center Energy Efficiency I
\end{tabular}

TII-2 Data Center Energy Efficiency II

TII-3 LEDs and Photovoltaics

TII-4 Power Electronics

TII-5 Immersion Cooling and Refrigeration

TII-6 Data Center and Energy Efficiency III

TII-8 Space, Aerospace, and Telecommunications

TII-9 Automotive, Batteries, and Thermal Storage

TII-10 Data Center Energy Efficiency IV

TII-11 Mobile, Internet of Things I

TII-12 Mobile, Internet of Things II

\section{MECHANICS \& RELIABILITY}

M-1 $\quad$ Applied Reliability and Failure Analysis

M-2 Advanced Methodologies for Reliability

M-3 Mechanics in Assembly and Packaging I

M-4 Mechanics in Assembly and Packaging II

M-5 Modeling and Analytical Methods for Mechanics and Reliability of Electronic Packaging I

M-6 Modeling and Analytical Methods for Mechanics and Reliability of Electronic Packaging II

M-7 Solder Joint Reliability I

M-8 Solder Joint Reliability II

M-9 Solder Characterization and Modeling I

M-10 Solder Characterization and Modeling II

M-11 Thermal-Mechanical Interactions in Microelectronics Packages and Systems

M-12

Thermal-Mechanical Interactions in Microelectronics Packages and Systems II
違いは, データセンター, サーバに関するトラックやセッ ションが毎年複数設定されていることである。筆者の知る 限り，このトレンドは少なくとも 2010 年代初頭には始まっ ており,アメリカにおけるコンピュータ産業の重要性を物 語る一面ではないかと考える。

\subsection{InterPACK2018}

InterPACK2018 は 8 月 27 日から 8 月 30 日の 4 日間，カリ フォルニア州サンフランシスコで開催された。キーノート, パネルデイスカッション, チュートリアルやワークショッ プ，口頭発表，ポスターなど，10 のトラックを有し，口頭 発表はそのうち 5 つのラックとして構成された ${ }^{6}$ 。

表 2 に InterPACK2018 における口頭発表のトラックとセッ ションを一覧で示す。InterPACKでは 2017 年からアプリケー ション別にトラックが構成されるようになったが，その中

表 2. InterPACK2018 Tracks and Sessions

\begin{tabular}{l|l}
\hline \multicolumn{2}{l}{ 1. Heterogeneous Integration: Micro-Systems With Diverse Functionality } \\
\hline $1-1$ & Fundamentals of Thermal Transport -1 \\
$1-2$ & Thermal Management Applications - 1 \\
1-3 & Thermal Management Applications - 2 \\
$1-4$ & Microelectronics Packaging \\
$1-5$ & Microfabrication \\
$1-6$ & Design and Characterization \\
$1-7$ & Fundamentals of Thermal Transport - 2 \\
\hline
\end{tabular}

2. Servers of the Future, IoT, and Edge to Cloud

2-1 $\quad$ Data Center Cooling 1

2-2 Data Center Cooling 2

2-3 Server Cooling 1

2-4 Server Cooling 2

2-5 Two-Phase Flow

2-6 Reliability in Cooling Systems

2-7 Advanced Cooling Technology

3. Structural and Physical Health Monitoring

3-1 Design, Materials and Characterization

3-3 Mechanical Reliability I

3-4 Applications and system level challenges

3-5 Mechanical Reliability II

4. Power Electronics, Energy Conversion, and Storage

4-1 Wide Bandgap Electronics

4-2 Wide Bandgap Optoelectronics

4-3 Ultra-Wide Bandgap Materials

4-4 Ultra-Wide Bandgap Devices

4-5 Power Electronics Packaging - Enhanced Functionality

4-6 Power Electronics Packaging - Processing

4-7 Power Electronics Packaging - Reliability Physics

4-8 Power Electronics Packaging - Reliability Testing

4-9 Power Electronics Packaging - Functional Materials

4-10 Power Electronics Packaging - Thermal Interface Materials

4-11 Power Electronics Thermal Management - Embedded Cooling

4-12 Power Electronics Thermal Management - Two Phase Heat Transfer

4-13 Power Electronics Thermal Management - Heat Exchangers and Heat Pipes

4-14 Power Electronics Thermal Management - System Level

4-15 Power Electronics Thermal Management - Components and Materials

4-16 Power Electronics Thermal Management - Thermoelectrics and Emerging

Cooling Techniques

4-17 Batteries, Photovoltaics, and Energy Harvesting Devices

4-18 Low Dimensional Materials and Nanoscale Heat Transfer

5. Autonomous, Hybrid, and Electric Vehicles

5-1 $\quad$ Package and system reliability

5-2 Packaging Materials

5-3 Electronics for Novel Drivetrain Technologies

5-4 PHM for Automotive Systems

5-6 Sensors and components for high temperature and harsh environment 
で昨年比最も大きな躍進を遂げたのは“Power Electronics, Energy Conversion, and Storage” トラックである。2017 年に は “Energy Conversion \& Storage”として構成されていた が, ワイドバンドギャップ半導体とパワーエレクトロニク スに関するセッションが 2017 年の 5 つから 2018 年は 18 と 大幅に増加し，トラック名にも“Power Electronics”の文字 が入るようになった。“Power Electronics, Energy Conversion, and Storage” トラックの発表が全体の半分弱を占めるよう になったのは印象的である。その中で, パワーエレクトロ ニクスのサーマルマネージメント研究だけで, 4-10から 4-16までの 7 セッションが組まれた。

なお, InterPACK2018 では, 日本のサーマルマネージメ ント研究に特筆すべきイベントがあった。富山県立大学で 学長を務められている石塚勝先生が 2017 年の選考で日本人 として初の Allan Kraus Thermal Management Medal ${ }^{7)}$ を受賞 され, InterPACK2018 開催 2 日目のランチョンセッション としてキーノートスピーチを行ったことである。機器の電 動化が進む昨今, 今後ますます重要となるサーマルマネー ジメント研究にとって, 絶妙な夕イミングで石塚先生が受 賞されたことは非常に感慨深く, また, 今後その担い手と なる研究者, 技術者の育成の重要性を改めて感じる次第で ある。

\section{4. おわりに}

本稿では, サーマルマネージメント研究に関連する, 2018 年度に開催された国際学術会議および国内の学術講演 会の中から, 代表的なものをいくつか取り上げ, 口頭発表 の研究動向を紹介した。2019年にも今回紹介した講演会は 引き続き開催される予定である。国内開催の学術国際会議 である ICEP2019 は 4 月 17 日から 4 月 20 日まで新潟県新 潟市にある朱鴽メッセにて, 国内の学術講演会である第 56 回日本伝熱シンポジウムは 5 月 29 日から 5 月 31 日まで徳 島県德島市にあるあわぎんホールにて, 熱工学コンファレ ンス 2019 は 10 月 12 日から 10 月 13 日まで名古屋工業大学
にて，それぞれ開催予定である。アメリカで開催される ITherm2019は 5 月 28 日から 5 月 31 日までネバダ州ラスベ ガスにて, InterPACK2019は10月 7 日から 10 月9日まで カリフォルニア州アナハイムにて, 開催予定である。いず れの学術講演会も, 情報発信, 情報収集, 情報交換の良い 機会となると思われる。

文責 ·西 剛伺 $/$ 足利大学 (2018.11.1- 受理)

\section{文献}

1) エレクトロニクス実装学会 : Proceedings of ICEP-IAAC2018, 2018 年 4 月

2) 日本伝熱学会 : 第 55 回日本伝熱シンポジウム講演論文集, 2018 年 5 月

3) 日本機械学会：熱工学コンファレンス 2018 講演論文集, 2018 年 10 月

4) 畠山友行, 松本圭司: “サーマルマネージメント研究の動 向,”エレクトロニクス実装学会誌, Vol. 21, No. 1, pp. 6669,2018 年 1 月

5) IEEE : Final Conference Program ITherm2018， 2018 年 5 月

6) ASME : Proceedings of InterPACK2018，2018 年 8 月

7) Allan Kraus Thermal Management Medal, https://www.asme. org/about-asme/get-involved/honors-awards/achievementawards/allan-kraus-thermal-management-medal (Access Date: 2018/10/31)

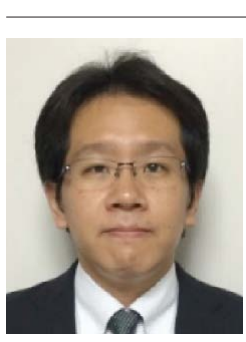

西 剛伺（にしこうじ）

著者紹介 足利大学工学部創生工学科講師。サーマルマネー ジメント研究会委員。電子機器の小型・省エネ化 研究に従事。 